UDC 612.014.45:612.015.3:611.018.4]-073.77-092.9

https://doi.org/10.26641/2307-0404.2021.1.227726

\author{
N.M. Kostyshyn ${ }^{1}$, \\ M.R. Gzhegotskyi ${ }^{1}$, \\ O.A. Yarova ${ }^{3}$, \\ L.P. Kostyshyn ${ }^{2}$, \\ Yu.O. Kulyk ${ }^{4}$
}

\section{EFFECT OF WHOLE BODY VIBRATION ON BONE NANOCOMPOSITES ORGANISATION AND PREVENTION OF LOSS OF BONE MINERAL DENSITY UNDER CONDITIONS OF MODELING OBESITY AND SEDENTARY LIFESTYLE: EXPERIMENTAL STUDY}

Danylo Halytsky Lviv National Medical University

department of Normal Physiology ${ }^{1}$

Pekarska str., 52, Lviv, 79010, Ukraine

department of Toxicological and Analytical Chemistry ${ }^{2}$

Pekarska str., 69, Lviv, 79010, Ukraine

Ivan Franko National University

department of Theoretical and Applied Statistics ${ }^{3}$

Universytetska str., 1, Lviv, 79005, Ukraine

department of Metal Physics ${ }^{4}$

Kyryla and Mefodiya str., 8, Lviv, 79005, Ukraine

Львівський національний медичний університет ім. Данила Галицького

кафедра нормальної фізіології ${ }^{1}$

(зав. - проф. О.С. Заячківська)

вул. Пекарська, 52, Львів, 79010, Украӥна

кафедра токсикологічної та аналітичної хімії ${ }^{2}$

(зав. - дои. І.Й. Галькевич)

вул. Пекарська, 69, Львів, 79010, Україна

Львівський начіональний університет імені Івана Франка

кафедри теоретичної та прикладної статистики

(зав. - проф. Я.І. Слейко)

вул. Університетська, 1, Львів, 79005, Україна

кафедра фізики металів ${ }^{4}$

(зав. - проф. С.I. Мудрий)

вул. Кирила і Мефодія, 8, Львів, 79005, Украӥна

e-mail:kostyshyn.nm@gmail.com

Цитування: Медичні перспективи. 2021. Т. 26, № 1. С. 30-39

Cited: Medicni perspektivi. 2021;26(1):30-39

Key words: whole body vibration, bone remodeling, bone mineral density, osteoporosis, X-ray diffraction Ключові слова: загальна вібрачія, ремоделювання кісткової тканини, мінеральна щільність, остеопороз, рентгенівська дифракиія

Ключевые слова: общая вибрация, ремоделирование костной ткани, минеральная плотность, остеопороз, рентгеновская дифракичия

\begin{abstract}
Effect of whole body vibration on bone nanocomposites organisation and prevention of loss of bone mineral density under conditions of modeling obesity and sedentary lifestyle: experimental study. Kostyshyn N.M., Gzhegotskyi M.R., Yarova O.A., Kostyshyn L.P., Kulyk Yu.O. This study aimed to investigate the influence of high-frequency whole body vibration (WBV) on metabolic and structural responses of rats' bone tissue under the sedentary lifestyle and obesity. Obesity combined with a sedentary lifestyle can present the potential negative health effects. However, whole body vibration can be used as a means of non-pharmacological correction of bone mineral density. For characterization of bone nanocomposites organisation and prevention of mineral density loss, $X$ ray diffraction method was used. Markers of bone remodeling in the rats' blood: leptin, osteocalcin, tartarate resistant acid phosphatase 5b, alkaline phosphatase. Using a high-calorie diet and low-mobility model, we proved that bone mineral mass had been decreasing since $8^{\text {th }}$ week. It should be noted that the decrease in the relative amount of crystalline phase (hydroxyapatite) continued throughout the experiment, up to 24 weeks $(p<0.05)$. These structural changes were accompanied by changes in quantitative indicators of the bone remodeling markers. Rats had lower bone mineral density compared to the animals that were on the normal diet and were additionaly affected by WBV. We
\end{abstract}


observed the increase of the crystalline phase volume fraction from $84 \%$ to $93 \%(p<0.05)$ in group with additional whole body vibration and the decrease of the mineral component in rats with limited mobility and high-calorie diet. Therefore, WBV could improve structural conditions of bone and prevent fat accumulation and obesity-associated biochemical markers in obese rats. This can be an effective method to improve the structural and functional state of the bones while preventing the loss of bone mineral density.

Реферат. Вплив загальної вібрації на організацію кісткових нанокомпозитів та запобігання втрати мінеральної маси кісткової тканини за умови моделювання ожиріння та обмеженої рухомості: експериментальне дослідження. Костишин Н.М., Гжегоцький М.Р., Ярова О.А., Костишин Л.П., Кулик Ю.О. Це дослідження мало на меті дослідити вплив високочастотної загальної вібрації на метаболічні та структурні зміни кісткової тканини щурів за умови моделювання ожиріння та обмеженої рухомості. Поєднання ции двох факторів може представляти потениійні негативні наслідки для здоров'я та стану кісткової тканини зокрема. У літературі зустрічаються дані, шуо вказують на можливість застосування механічних коливань, з певним віброприскоренням, як засобу нефармакологічної корекції мінеральної щільності кістки. Для характеристики організації кісткових нанокомпозитів та запобігання втрат мінеральної маси застосовували рентгеноструктурний аналіз підготовленого кісткового порошку. Визначали ичитокіни жирової тканини та маркери ремоделювання кісток у крові щурів: лептин, остеокальцин, тартратрезистентну кислу фосфатазу, лужну фосфатазу. Використовуючи висококалорійну дієту та модель з обмеженою рухомістю, ми довели, щз мінеральна маса кісток зменшується вже з 8-го тижся експерименту. Слід зазначити, щзо зниження відносної кількості кристалічної фази (гідроксиапатиту) тривало протягом усього експерименту аж до 24-го тижня дослідження (р<0,05). Ці структурні зміни супроводжувалися зміною кількісних показників маркерів ремоделювання кісток. Щурі мали меншу мінеральну масу кісток порівняно з тими тваринами, які перебували на звичайному харчуванні та на яких додатково впливали загальними механічними коливаннями. При иььому спостерігали збільшення обсягу фракції кристалічного компонента з 84\% до 93\% $(p<0,05)$ у групі з механічною стимуляцією та зниженням мінерального компонента у шурів з обмеженою рухливістю та висококалорійною дієтою. Установлено, щзо загальна вібрація покращує структурнофункиіональний стан кісток $і$ запобігає накопиченню жиру, про щзо свідчать зміни біохімічних маркерів у дослідних щурів. Тому фізичні навантаження є ефективним методом для поліпшення стану кісток та можуть використовуватися як доповнення до фармакологічної терапії остеопорозу.

Obesity and a sedentary lifestyle are risk factors for chronic health disorders such as heart disease, diabetes type 2, osteoporosis, etc. [13]. However, there is evidence of these factors' positive impact on bone tissue formation through the increased mechanical stress $[11,12]$, that can stimulate the bone tissue remodeling by reducing apoptosis of osteoblasts and osteocytes, increasing their proliferation and differentiation $[10,17]$. Therefore, the assumption that obesity leads to an increase of mechanical stress on the bone and facilitates the prevention of osteopenia is fallacious. Reduced functional stress leads to the decrease both of the bioelectric potentials and circulation intensity, which inhibits bone formation and stimulates resorption of the bone tissue $[2,14,15,16]$. Lack of exercise causes reduced microvasculature capacity and capillary network, when the first signs of bone atrophy and osteoporosis are manifested, and long-term reduction of functional stress may cause irreversible changes in the bone tissue. As a result, the regressive transformation of bone leads to increased porosity and osteoporotic fractures of bone structures, even under minimal stress [7,9]. Despite conflicting data, the pathophysiological connection between obesity, sedentary lifestyle and bone mineral density (BMD) loss is rather complicated and requires further study. The majority of researches is devoted to studying the influence of high frequency vibration acceleration $\leq$ $0.5 \mathrm{~g}$. In particular, Rubin and McLeod proved high bone sensitivity to mechanical stimuli. By modelling general vibration fluctuations with the frequency of $30 \mathrm{~Hz}$ and vibratory acceleration of $0.3 \mathrm{~g}$ for $5 \mathrm{~min}$ daily within 30 days, the scholars have determined bone mass acquisition in the trabecular layer of turkeys' tibia. Much later, Rubin et al., 1994, proved anabolic effect of the aforementioned fluctuations and deceleration of remodelling bone tissue by means of retardation of osteoclastogenesis processes (downregulation of RANKL and cytokines related to osteoclastogenesis).

The aim was to study the influence of highfrequency whole body vibration on the process of remodeling of the rats' bone tissue under the sedentary lifestyle and obesity conditions. For characterization of bone nanocomposites organisation and prevention of bone mineral density loss Xray diffraction method was used [3, 4]. We determined markers of bone remodeling in the rats' blood, which allow the definition of actual bone metabolism.

\section{MATERIALS AND METHODS OF RESEARCH}

The experimental study was performed on 54 male rats of the Wistar line weighing 180-200 g, kept under the same vivarium conditions. All animal experiments were conducted in compliance with 
bioethical principles per the provisions of the European Convention for the Protection of Vertebrate Animals used for Experimental and Other Scientific Purposes (Strasbourg, 1986), Council Directive 86/609/EEC (1986), Law of Ukraine No. 3447-IV On the Protection of Animals from Cruelty, General Ethical Principles of Animal Experiments, approved by the First National Congress of Ukraine on Bioethics (2001).

The experimental rats were divided into 3 groups, 18 rats in each: control group - standard vivarium conditions, I experimental group - limited mobility condition + high-calorie diet (LMC+HCD), II experimental group - LMC $+\mathrm{HCD}+\mathrm{WBV}$. Obesity condition was modeled through a high-calorie diet (C 11024, Research Diets, New Brunswick, NJ); limited mobility condition was modeled using partition cages to restrict the rats' mobility. All experimental rats were weighed every two weeks. Vertical vibration oscillations were modeled using a $250 \mathrm{~W}$ vibrating table with the maximum pressure of $7 \mathrm{bar}$ and $50 \mathrm{~Hz}$ frequency, $\mathrm{g}-0.3$. After the $8^{\text {th }}$, the $16^{\text {th }}$ and the $24^{\text {th }}$ week, six animals from each group were removed from the experiment by decapitation under general intraperitoneal anesthesia at $0.3 \mathrm{~g} / \mathrm{kg}$.

Concentrations of cytokines and bone remodeling markers in blood plasma were determined using commercial immune-enzyme analysis kits (ELISA). We determined leptin (anti-Leptin (rat), pAb, AdipoGen Life Sciences, osteocalcin (DRG ${ }^{\circledR}$ Mouse Osteocalcin ELISA); Mouse Tartarate Resistant Acid Phosphatase 5B (TRAP5B) ELISA Kit, MyBioSource. The activity of alkaline phosphatase in blood serum was performed through photocolorimetry. All analyses were performed according to the manufacturer's instructions $[5,8]$.

To study the ultrastructure of the bone mineral component we used the method of X-ray diffraction analysis. The femur was dried at $110^{\circ} \mathrm{C}$ in a drying cabinet. The X-ray diffraction spectra of the samples were obtained on an automated X-ray diffractometer DRON-3 in $\mathrm{Cu} \mathrm{K} \alpha$ radiation $(\lambda=1.5418 \AA)$, monochromatized by reflection from a plane (002) of a single pyrographite crystal, mounted on a diffracted beam. We used the Bragg-Brentano focusing scheme $(\theta-2 \theta)$. [3, 4, 6, 8].The diffraction patterns were recorded in the continuous movement mode of the detector with an angular velocity of $2 \% \mathrm{~min}$, a constant value of the integration time $\tau=1 \mathrm{~s}$., $\mathrm{x}$-ray tube voltage at $\mathrm{U}=26 \mathrm{kV}$, and anode current at $\mathrm{I}=15 \mathrm{~mA}$. To estimate the quantitative content of the amorphous and crystalline phases we used the following ratios:

$$
X_{a m .}=\frac{I_{a m}}{\left(I_{a m}+I_{c r}\right)}, X_{c r}=1-X_{a m .}
$$

$\left(I_{a m}\right.$ - the maximum intensity from the amorphous phase, measured at $2 \theta \approx 21,5^{0}$

$I_{c r}$ - the maximum intensity of the crystalline phase, measured at $2 \theta \approx 32,1^{0}$, while taking into account the background scattering).

Statistical analysis of the data was performed in StatSoft STATISTICA 8.0.360. In the STATISTICA package, the comparison of two average samples of normally distributed features (Student's t-criterion) was implemented in the Basic Statistics/Tables module. The t-test, independent, by variable submodule, was used for two different general summations. One-way ANOVA is implemented in the Breakdown \& one-way ANOVA submenu of the Basic Statistics and Tables module [1].

\section{RESULTS AND DISCUSSION}

The rats' weight in I group (HCD+LMC) increased from $194.63 \pm 6.1 \mathrm{~g}$ to $340.82 \pm 8.62 \mathrm{~g}$ in the $24^{\text {th }}$ week, which indicates a statistically significant increase in weight compared to the control group $(\mathrm{p}<0.014)$. In the HCD+LMC+WBV group, the rats' weight increased from $198.3 \pm 6.61 \mathrm{~g}$ to $304.93 \pm 5.07 \mathrm{~g}$ in the $24^{\text {th }}$ week, respectively ( $\left.>0,05\right)$, the experimental group was not statistically different, Fig. 1.

Leptin is the primary hormone involved in the regulation of body weight. While increasing weight by $10 \%$, the level of serum leptin may become more than 3 times higher. Therefore, to assess energy metabolism, it is advisable to determine its concentration. In the $8^{\text {th }}$ week of the experiment, the leptin level in control group was $5.25 \pm 0.42 \mathrm{ng} / \mathrm{ml}$, in I experimental group it amounted to $15.01 \pm 1.19 \mathrm{ng} / \mathrm{ml}$ $(\mathrm{p}=0.000007)$, and in II $-11.13 \pm 1.71 \mathrm{ng} / \mathrm{ml}(\mathrm{p}=0.004)$. In the 16th week of the experiment, the dynamics of leptin levels was the following: in the control group it remained nearly unchanged at $5.91 \pm 0.35 \mathrm{ng} / \mathrm{ml}$, in I experimental group the average level was at $21.01 \pm 1.95 \mathrm{ng} / \mathrm{ml} \quad(\mathrm{p}=0.000008)$, in II $16.07 \pm 1.84 \mathrm{ng} / \mathrm{ml}(\mathrm{p}=0.00014)$. In the $24^{\text {th }}$ week of the experiment: the control group showed $4.93 \pm 0.25 \mathrm{ng} / \mathrm{ml}$, I experimental group $24.51 \pm 2.29 \mathrm{ng} / \mathrm{ml} \quad(\mathrm{p}=0.000003)$, and II $18.07 \pm 1.67 \mathrm{ng} / \mathrm{ml}(\mathrm{p}<0.032)$ (Fig. 2A). Regression analysis found that the mass depends on the level of leptin and is described by the equation: Weight $=179.51-6.4 *$ Leptin, with a correlation coefficient of 0.98 .

To determine bone remodeling we investigated bone formation markers - osteocalcin, alkaline phosphatase and bone resorption marker - TRAP- 5 b. Blood analysis showed significant differences in osteocalcin levels between the control and experimental groups of rats (Fig. 2B). In the $8^{\text {th }}$ week of the experiment, the concentration of osteocalcin in the control group was at $43.12 \pm 2.72 \mathrm{ng} / \mathrm{ml}$, in II experimental group $-41.33 \pm 2.58 \mathrm{ng} / \mathrm{ml}(\mathrm{p}=0.62>0.05)$, and $\mathrm{II}-65.37 \pm 3.89 \mathrm{ng} / \mathrm{ml}(\mathrm{T}=-5.13, \mathrm{p}<0.01)$. In the 
$16^{\text {th }}$ week of the experiment, there were the following changes in the osteocalcin level: in the control group it remained practically unchanged at $46.12 \pm 2.84 \mathrm{ng} / \mathrm{ml}$, in I experimental group the average was at $38.7 \pm 2.11 \mathrm{ng} / \mathrm{ml}(\mathrm{p}=0.021)$, and in II
$-73.27 \pm 3.44 \mathrm{ng} / \mathrm{ml}(\mathrm{p}=0.000052)$. In the $24^{\text {th }}$ week of the experiment in the control group the osteocalcin level was at $44.68 \pm 1.99 \mathrm{ng} / \mathrm{ml}$, in I experimental group at $39.0 \pm 4.05 \mathrm{ng} / \mathrm{ml}(\mathrm{p}>0.05)$, and in II - at $76.15 \pm 4.29 \mathrm{ng} / \mathrm{ml}(\mathrm{p}=0.0004)$.

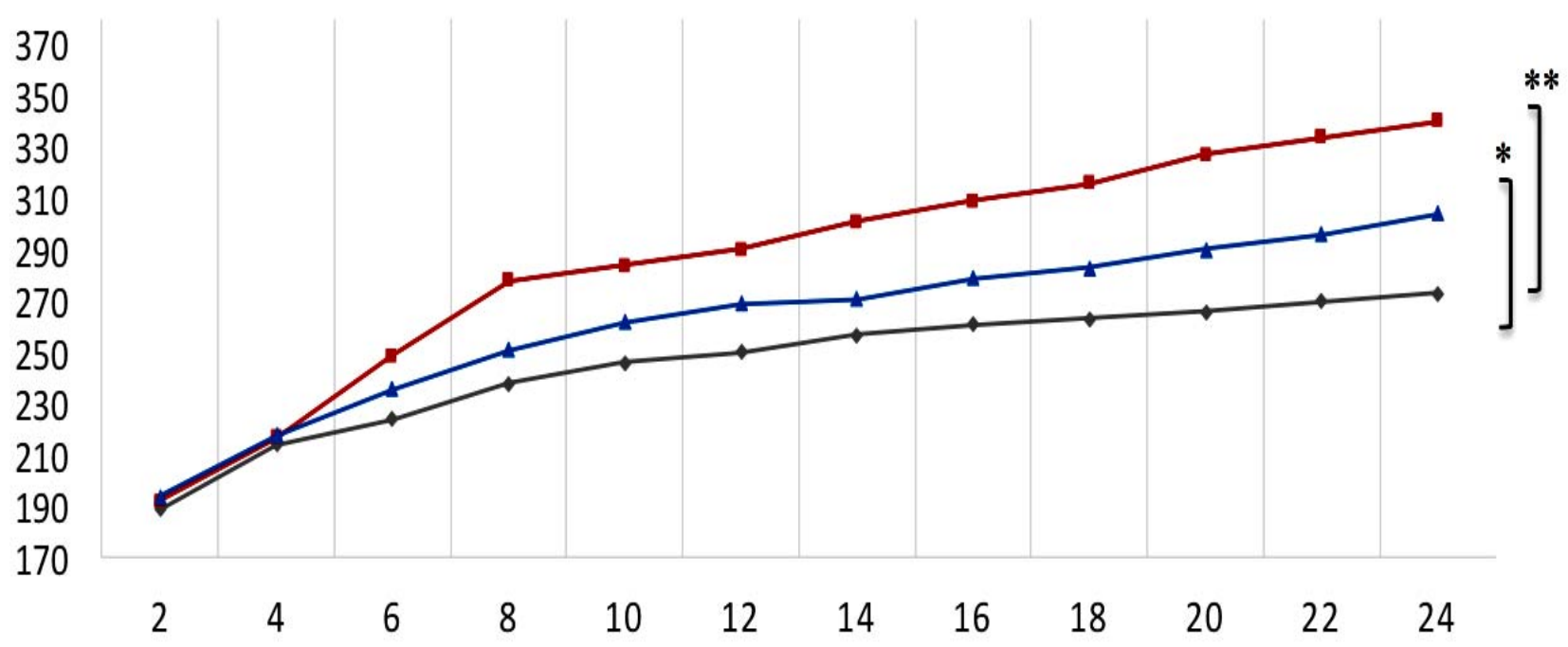

control group; $\square$ limited mobility + high-calorie diet; $\square$ limited mobility + high-calorie diet + WBV

Notes: * - groups do not differ statistically $\mathrm{p}>0,05$;

** - groups differ statistically at $\mathrm{p}<0,05$.

Fig. 1. Body weight

In the $8^{\text {th }}$ week of the experiment, the indicator of the alkaline phosphatase (APH) level between the control and experimental groups of rats (Fig. 2C) was at $353.16 \pm 13.92 \mathrm{U} / \mathrm{L}, 318.0 \pm 13.94 \mathrm{U} / \mathrm{L}(\mathrm{p}>0.05)$ in I experimental group and $363.82 \pm 10.7 \mathrm{U} / \mathrm{L}$ ( $>0.05$ ) in II. In the $16^{\text {th }}$ week of the experiment the dynamics of the APH level was the following: in the control group the indicator remained almost unchanged and amounted to $226.42 \pm 10.09 \mathrm{U} / \mathrm{L}$, in I experimental group the average value was at $203.58 \pm 19.79 \mathrm{U} / \mathrm{L} \quad(\mathrm{p}>0.05)$ and in II $375.05 \pm 9.07 \mathrm{U} / \mathrm{L}(\mathrm{p}<0.01)$. In the $24^{\text {th }}$ week of the experiment the indicator was at $209.71 \pm 9.55 \mathrm{U} / \mathrm{L}$ in the control group, $175.72 \pm 16.15 \mathrm{U} / \mathrm{L}(\mathrm{p}>0.05)$ in I experimental group and $326.9 \pm 19.79 \mathrm{U} / \mathrm{L}(\mathrm{p}=0.00007)$ - in II group.

TRAP-5b levels in the control and experimental groups of rats are presented in Fig. 2D. In the $8^{\text {th }}$ week of the experiment the TRAP-5b level in the control group of animals was at $4.62 \pm 0.29 \mathrm{U} / \mathrm{L}$, in I experimental group at $5.23 \pm 0.25 \mathrm{U} / \mathrm{L}(\mathrm{p}>0.05)$, in I group at $2.45 \pm 0.2 \mathrm{U} / \mathrm{L}(\mathrm{p}=0.000057)$. In the $16^{\text {th }}$ week of the study, the dynamics of the TRAP-5b level was the following: in the control group the index remained practically unchanged and amounted to $3.8 \pm 0.2 \mathrm{U} / \mathrm{L}$, in the I experimental group the average value was at $5.42 \pm 0.33 \mathrm{U} / \mathrm{L}(\mathrm{p}=0.001)$, at II $-2.51 \pm 0.24 \mathrm{U} / \mathrm{L}(\mathrm{p}=0.001)$. In the $24^{\text {th }}$ week of the experiment, the indicator was at $3.9 \pm 0.24 \mathrm{U} / \mathrm{L}$ in the control group, $6.83 \pm 0.25 \mathrm{U} / \mathrm{L} \quad(\mathrm{p}=0.000003)$ in I experimental group, $4.84 \pm 0.26 \mathrm{U} / \mathrm{L}(\mathrm{p}=0.000007)$ in II group.

Correlation analysis of bone cytokines: the coefficient of determination -0.84 indicates the adequacy of the constructed model of regression equation (Osteocalcin level and phosphatase level dependent on Spearman correlation coefficient level $-0,88$ (inverse); Osteocalcin level and TRACP-5 level dependent on Spearman correlation coefficient level - 0.83 (inverse); Phosphatase level and leptin level dependent on Spearman correlation coefficient level 0.88 (direct). 


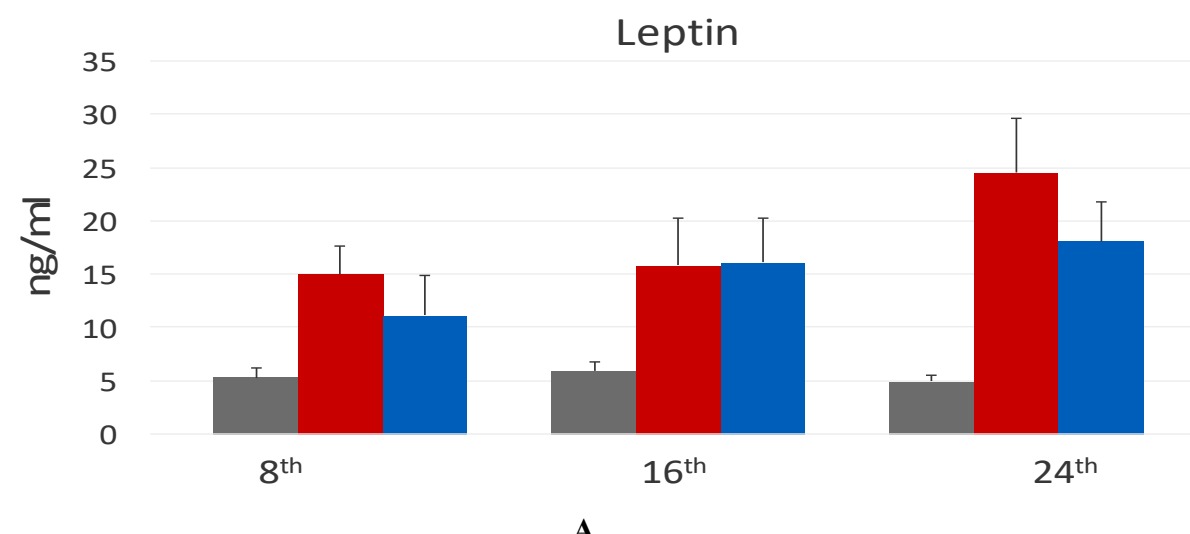

Osteocalcin
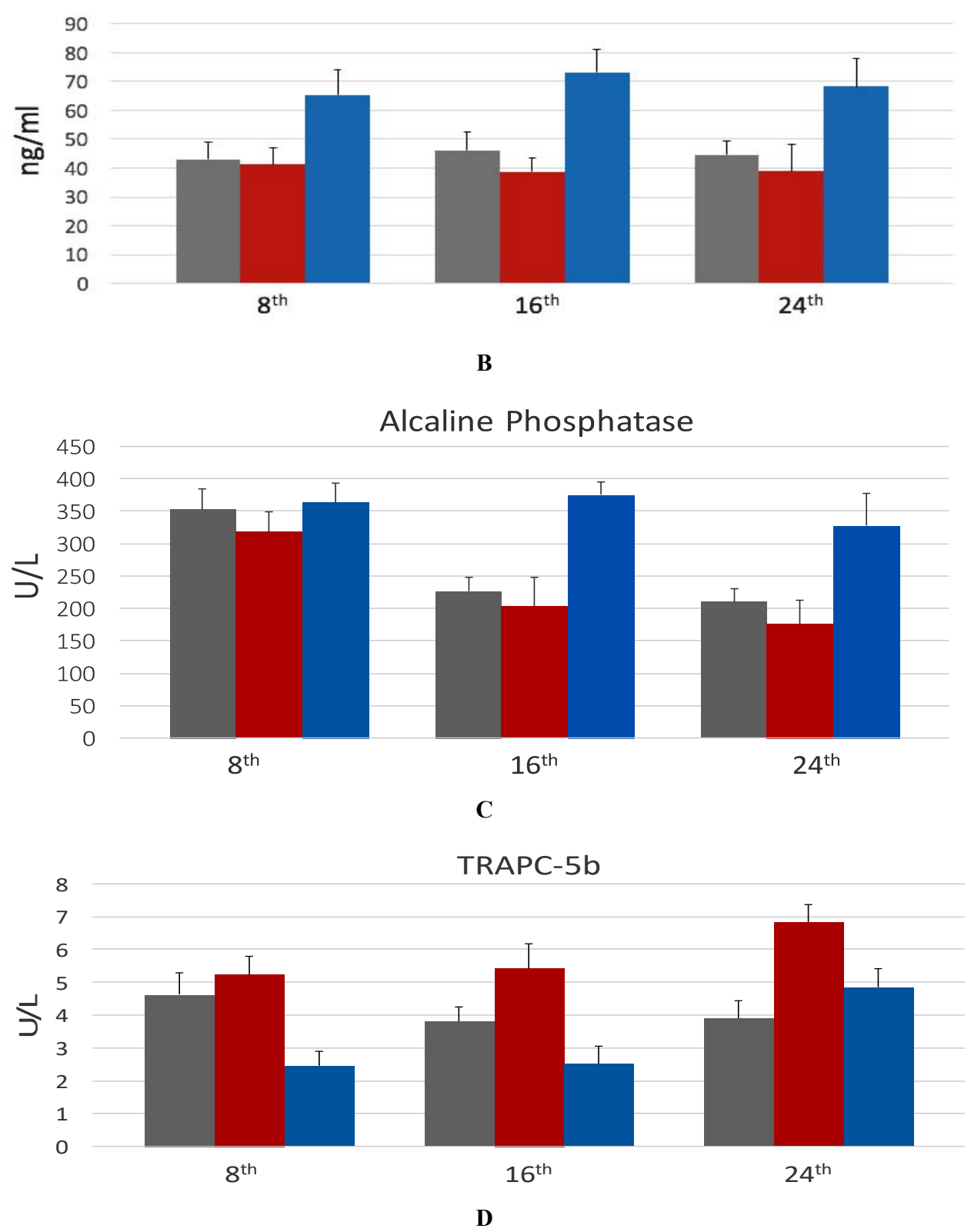

Fig. 2. Cytokines levels and bone remodeling markers in serum

(A - concentration of leptin, $\mathrm{ng} / \mathrm{ml}$; B - concentration of osteocalcin, $\mathrm{ng} / \mathrm{ml}$;

C - concentration of alkaline phosphatase, $U / L$; D - concentration of TRAC-5b, U/L;) 
The diffraction patterns of the femur series samples are shown in Fig. 4 compared to the theoretical diffraction pattern of the $\mathrm{Ca}_{10} \mathrm{P}_{6} \mathrm{O}_{26} \mathrm{H}_{2}$ chemical compound (hexagonal syngony, space group P $63 / \mathrm{m}$, unit cell parameters $a=9.42 \AA, c=6.88$ $A)$. Significant erosion of the diffraction maxima of the $\mathrm{Ca}_{10} \mathrm{P}_{6} \mathrm{O}_{26} \mathrm{H}_{2}$ crystalline phase indicates a low degree of crystallinity of the compound due to the small size of the coherent scattering regions (the crystallite size does not exceed $10 \mathrm{~nm}$ ). Also, a wide diffuse halo is observed in the diffraction patterns around the diffraction angle $2 \theta \approx 21^{0}$, indicating the presence of an amorphous (disordered) phase represented by collagen fibers in the samples. In the series of samples, the highest content of the amorphous phase is observed in the control group. The decrease in the intensity of the diffuse maximum of I experimental group sample indicates a decrease in the content of the amorphous phase (fig. 3). At the same time, in the sample of II experimental group we observe both a decrease of the diffuse maximum and an increase in the intensity of the maxima of the crystalline phase, which is especially pronounced in the region of the most intense lines (211), (121), (112) and (300) of the $\mathrm{Ca}_{10} \mathrm{P}_{6} \mathrm{O}_{26} \mathrm{H}_{2}$ phase.

The calculations results are shown in Table 1. In the $8^{\text {th }}$ wk. $\rightarrow 16^{\text {th }}$ wk. $\rightarrow 24^{\text {th }}$ wk. sequence, we can observe the increase of the crystalline phase volume fraction from $84 \%$ to $93 \%,(p<0.05)$ in II experimental group and the decrease of the mineral component in I experimental group, $(\mathrm{p}<0.05)$, (Fig. 4, Table).

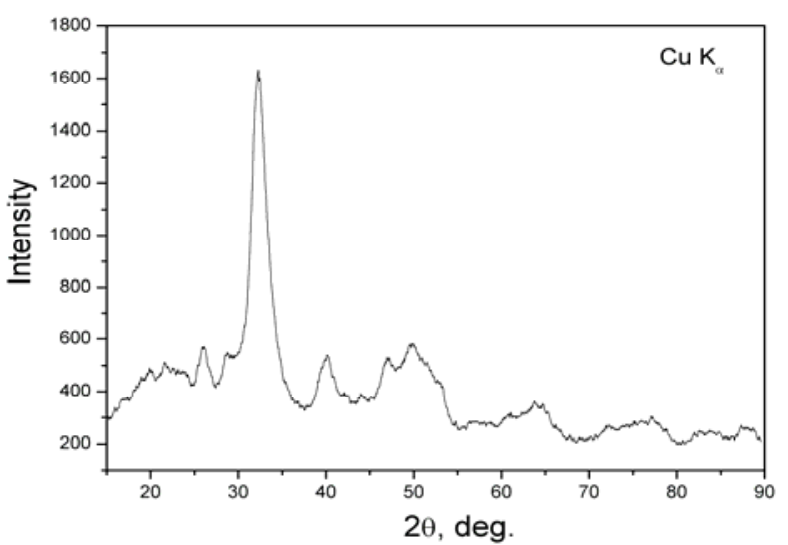

B

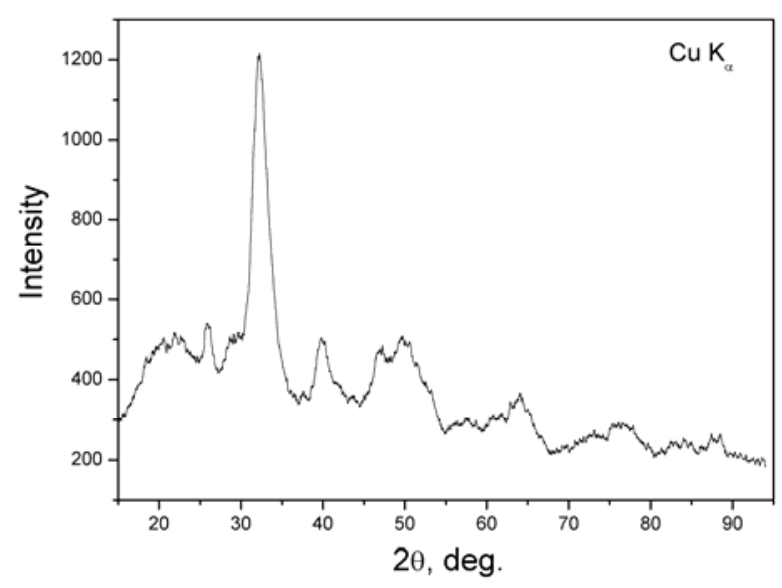

D

Fig. 3. A - XRD of bone nanocomposites in control group.

B, C, D - diffraction patterns of the rat's femur in I experimental group (HCD+LMC) in the $8^{\text {th }}, 16^{\text {th }}$ and $24^{\text {th }}$ week respectively. To determine the integral intensity of the hydroxyapatite reflex we chose the reflex of the $30-37^{\circ}$ angular range since it is of the highest intensity 


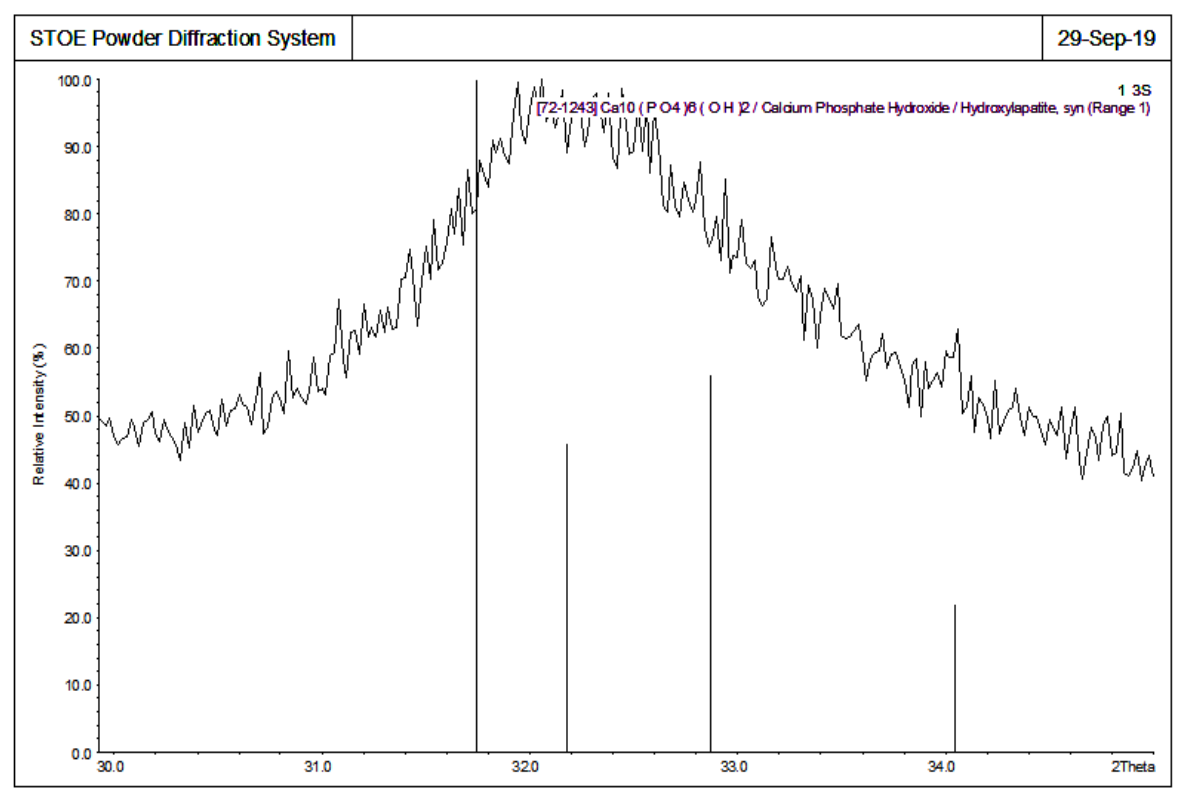

$\mathbf{A}$

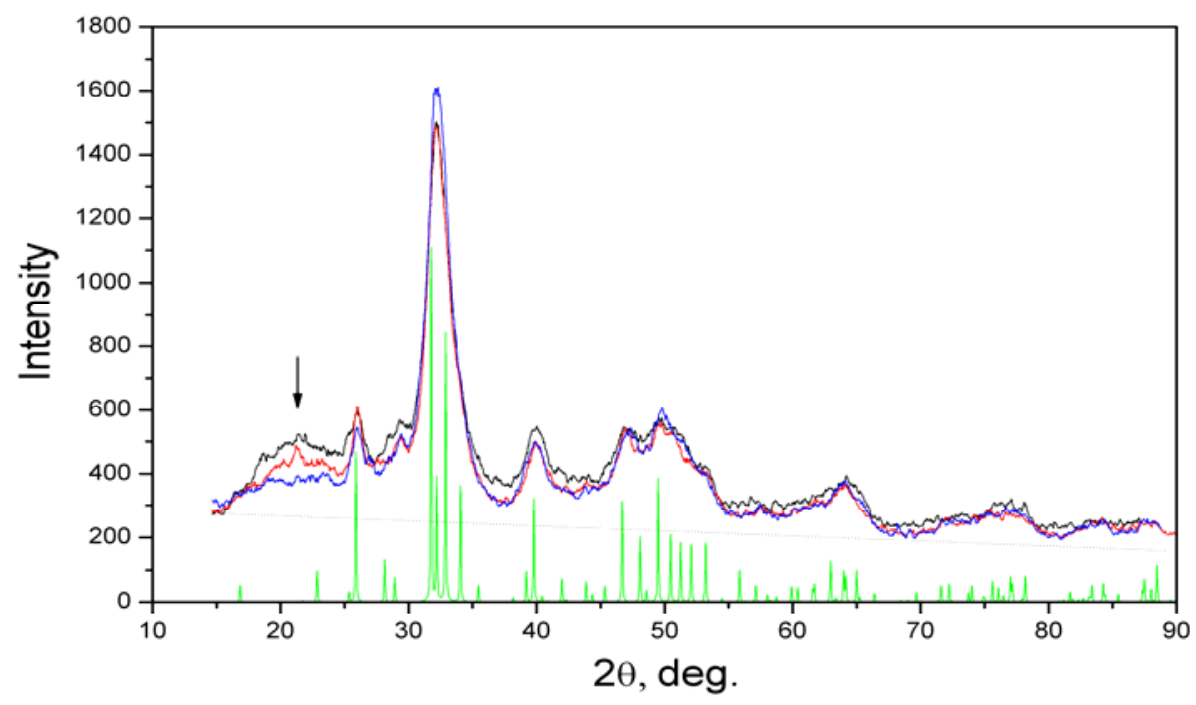

B

Fig. 4. A - Although this reflex consists of four reflexes of hydroxyapatite with Miller indices, the diffraction angles from the crystallographic planes are close to these indices: $31,741^{\circ} ; 32,179^{0} ; 32,868^{0}$ and $34,045^{\circ}, B_{-}$ Diffraction patterns of II experimental group samples (HCD+LMC+WBV) in $-8^{\text {th }} ;-16^{\text {th }} ;-24^{\text {th }}$ week. The arrow indicates the position of the amorphous phase diffuse maximum, while the dashed line indicates the background scattering

Using a high-calorie diet and low-mobility model, we proved that bone mineral mass had been decreasing since week 8 . These structural changes were accompanied by changes in quantitative indicators of the bone remodeling markers. In our experimental model, rats had lower bone mineral density compared to the animals that were on the normal diet and were further affected by WBV. It is clear that high-frequency mechanical oscillations activate osteoblasts, accelerate metabolic processes, and slow BMD decline. The obvious competitive impact of obesity and mechanical stress on bone 
metabolism requires further study [11, 12]. Our experiment suggests that excess fat does not prevent bone mineral decline and is often associated with an increased risk of osteoporosis and osteoporotic fractures, due to excessive pressure on the musculoskeletal system.

Volume fractions of amorphous and crystalline phases of the samples

\begin{tabular}{|c|c|c|c|c|}
\hline Group/week & $\mathbf{X}_{\mathrm{cr}}$ & $\mathbf{X}_{\mathrm{am}}$ & $\mathbf{B}_{(002)},{ }^{0}$ & $\mathbf{L}, \mathbf{n m}$ \\
\hline Control $8^{\text {th }}$ week & 0.83 & 0.17 & $1.123 \pm 0.05$ & $11.0 \pm 0.9$ \\
\hline Control $16^{\text {th }}$ week & 0.88 & 0.12 & $1.173 \pm 0.03$ & $12.0 \pm 0.5$ \\
\hline Control $24^{\text {th }}$ week & 0.85 & 0.15 & $1.170 \pm 0.06$ & $11.3 \pm 0.9$ \\
\hline HCD+LMC $8^{\text {th }}$ week & $0.82 * *$ & 0.18 & $1.618 \pm 0.09$ & $6.6 \pm 0.4$ \\
\hline HCD+LMC $16^{\text {th }}$ week & $0.80 *$ & 0.2 & $1.597 \pm 0.04$ & $7.9 \pm 0.3$ \\
\hline HCD+LMC $24^{\text {th }}$ week & $0.76 *$ & 0.24 & $1.237 \pm 0.03$ & $11.7 \pm 0.4$ \\
\hline HCD+LMC+WBV $8^{\text {th }}$ week & $0.84 * *$ & 0.16 & $1.244 \pm 0.05$ & $11.6 \pm 0.9$ \\
\hline HCD+LMC+WBV $16^{\text {th }}$ week & $0.88 *$ & 0.12 & $0.978 \pm 0.02$ & $16.4 \pm 0.8$ \\
\hline HCD+LMC+WBV $24^{\text {th }}$ week & $0.93 *$ & 0.07 & $0.961 \pm 0.03$ & $16.6 \pm 1.2$ \\
\hline
\end{tabular}

Notes: $*$ - groups differ statistically $\mathrm{p}<0.05 ; * *-$ groups do not differ statistically $\mathrm{p}>0.05 ; \mathrm{X}_{\mathrm{cr}}-$ the volume fraction of the crystalline phase. $\mathrm{B}_{(002)}-$ the half-width of the maximum $(002)$ of the $\mathrm{Ca}_{10} \mathrm{P}_{6} \mathrm{O}_{26} \mathrm{H}_{2}$ phase. $L$ - the average crystallite size of the $\mathrm{Ca}_{10} \mathrm{P}_{6} \mathrm{O}_{26} \mathrm{H}_{2}$ phase.

It is also known that obesity can affect bone metabolism through multiple mechanisms. Since adipocytes and osteoblasts originate from a common multipotent mesenchymal stem cell, obesity may increase adipocyte differentiation and fat accumulation, thus reducing differentiation of osteoblasts and bone formation [14]. A slight increase in proinflammatory cytokines which may also occur under obesity, may increase osteoclast activity and bone resorption through changes in the RANK/RANKL/OPG system. In the $\mathrm{HCD}+\mathrm{LMC}$ group there was an increase in serum leptin and TRAP-5b, while bone formation markers, osteocalcin and alkaline phosphatase were reduced. Leptin effect on bone is ambiguous, in particular, there are reports on both positive and negative effects. According to the literature, increased leptin level (as observed in our animal models with obesity) may have a negative impact on bone metabolism. We also found out that increased leptin level in blood serum is a negative regulator of bone mass that may occur through the cytokine inhibition of osteoblasts. The activated osteoclasts form the socalled "resorption holes" with low $\mathrm{pH}$ level, which are the areas of the inorganic matrix destruction. It should be noted that this process occurs due to the lysosomal enzymes, namely tartrate-resistant acid phosphatase (TRAP) and cathepsin K. It allows the efficient digestion of Type I collagen and its degradation products. Osteoblasts are drawn to the ruined surface and begin to form new osteoid. Type I collagen is secreted in the form of moleculeprecursor of procollagen into the extracellular space where it breaks down to amino- and carboxylterminal propeptides with their subsequent release into the bloodstream, accompanied by an increase in the alkaline phosphatase level. First crystals of hydroxyapatite are deposited in osteoid, then undergo a process of mineralization, which lasts a few months (for adults) and then this is followed by a period of physiological respite of the bone. We must note that about $70-90 \%$ of the osteoblast-synthesized osteocalcin is fused in the bone matrix, and the rest gets into the bloodstream. Therefore, it is considered the most particular protein of bone tissue. It is also known that bone consists of organic matrix and mineral phase structural units which are composed of hydroxyapatite crystals. Osteocalcin is located predominantly in mineralized tissue acting as a mediator for matrix mineralization and has a high affinity for calcium. After separation from osteoblasts, osteocalcin is deposited in the bone matrix and released into the blood, and therefore this marker may indicate the rate of bone remodeling. A rapid increase of the osteocalcin level in the rats' venous blood in II experimental group indicates the effect of high-frequency oscillation on bone metabolism and increased osteoblasts activity.

\section{CONCLUSIONS}

Thus, whole body vibration, with acceleration of $0.3 \mathrm{~g}$, have a positive effect on body weight, biochemical laboratory indicators of obesity and leads to normalization of body weight. Vibration can be used as a potential non-pharmacological correction of bone mineral density and has an antiresorptive effect for preventing bone loss in obesity. In particular, for individuals with obesity and sedentary lifestyle it is important not only to correct diet, but also to apply mechanical loads on to the 
musculoskeletal system, which was modelled by whole-body vibration platform. Therefore, vibration of the whole body with a vibration acceleration of $0,3 \mathrm{~g}$ can be considered as the method of weight correction and has a positive effect on the remodelingand structural state of bone nanocomposites.

Conflict of interest. The authors declare no conflict of interest.

This work was supported by the Department of Normal Physiology of Danylo Halytsky Lviv Natio- nal Medical University, "Researching the role of systemic and paracrine regulatory mechanisms in providing homeostasis of functional and metabolic parameters of the organ-ism under conditions of adaptation to extreme factors of diverse nature" (state registration number 0116U004510). Ethical approval. Ethics Commission Report No. 10, 16.12.2019, Danylo Halytsky Lviv National Medical University.

\section{REFERENCES}

1. Antamonov MY. [Mathematical processing and analysis of medical and biological data]. Kyiv; 2017.

2. Alavinia SM, Omidvar M, Craven BC. Does whole body vibration therapy assist in reducing fat mass or treating obesity in healthy overweight and obese adults? A systematic review and meta-analyses. Disability and Rehabilitation. 2019;1-13.

doi: https://doi.org/10.1080/09638288.2019.1688871

3. Bunaciu AA, UdriŞTioiu EG, Aboul-Enein HY. X-ray diffraction: instrumentation and applications. Critical reviews in analytical chemistry. 2015;45(4):289-99. doi: https://doi.org/10.1080/10408347.2014.949616

4. Clark SM, Iball J. The x-ray crystal analysis of bone. Progress in Biophysics and Biophysical Chemistry: Progress Series. 2016;7:226.

doi: https://doi.org/10.1016/S0096-4174(18)30127-6

5. Morris HA, Eastell R, Jorgensen NR, Cavalier E, Vasikaran S, Chubb SAP, et al. Clinical usefulness of bone turnover marker concentrations in osteoporosis. Clinica chimica acta. 2017;467:34-41.

doi: https://doi.org/10.1016/j.cca.2016.06.036

6. Londoño-Restrepo SM, Jeronimo-Cruz R, MillánMalo BM, Rivera-Muñoz EM, Rodriguez-García ME. Effect of the nano crystal size on the X-ray diffraction patterns of biogenic hydroxyapatite from human, bovine, and porcine bones. Scientific reports. 2019;9(1):1-12. doi: https://doi.org/10.1038/s41598-019-42269-9

7. Gritschmeier F, Lange KW. Health effects of whole body vibration. Movement and Nutrition in Health and Disease. 2020;4:83-88.

8. Hlaing TT, Compston JE. Biochemical markers of bone turnover-uses and limitations. Annals of clinical biochemistry. 2014;51(2):189-202.

doi: https://doi.org/10.1177/0004563213515190

9. Minematsu A, Nishii Y, Imagita H, Sakata S. Whole body vibration at low-frequency can increase trabecular thickness and width in adult rats. Journal of musculoskeletal \& neuronal interactions. 2019;19(2):169.

10. Pang MY, Lau RW, Yip SP. The effects of whole-body vibration therapy on bone turnover, muscle strength, motor function, and spasticity in chronic stroke: a randomized controlled trial. European journal of physical and rehabilitation medicine. 2013;49(4):439-50.

11. Savvidis C, Tournis S, Dede AD. Obesity and bone metabolism. Hormones. 2018;17(2):205-17. doi: https://doi.org/10.1007/s42000-018-0018-4

12. Shapses SA, Pop LC, Wang Y. Obesity is a concern for bone health with aging. Nutrition research. 2017; 39:1-13.

doi: https://doi.org/10.1016/j.nutres.2016.12.010

13. Smith KB, Smith MS. Obesity statistics. Primary care: clinics in office practice. 2016;43(1):121-35. doi: https://doi.org/10.1016/j.pop.2015.10.001

14. Li W, Xu P, Wang C, Ha X, Gu Y, Wang Y, Xie J. The effects of fat-induced obesity on bone metabolism in rats. Obesity Research \& Clinical Practice. 2017;11(4):45463. doi: https://doi.org/10.1016/j.orcp.2016.12.001

15. McGee-Lawrence ME, Wenger KH, Misra S, Davis CL, Pollock NK, Elsalanty M, et al. Whole-body vibration mimics the metabolic effects of exercise in male leptin receptor-deficient mice. Endocrinology. 2017;158(5):116071. doi: https://doi.org/10.1210/en.2016-1250

16. Zago M, Capodaglio P, Ferrario C, Tarabini M, Galli M. Whole-body vibration training in obese subjects: A systematic review. PloS one. 2018;13(9):e0202866. doi: https://doi.org/10.1371/journal.pone.0202866

17. Flores J, Jimenez A, Alonso A, Cervantes N, Hernandez $\mathrm{N}$, et al. Whole body vibration training with repetitive interval musculoskeletal loading on bone in young women. Southern California Conferences for Undergraduate Research; 2017.

\section{СПИСОК ЛІТЕРАТУРИ}

1. Антамонов М. Ю. Математическая обработка и анализ медико-биологических данных. Киев. 2017.

2. Alavinia S. M., Omidvar M., Craven B. C. Does whole body vibration therapy assist in reducing fat mass or treating obesity in healthy overweight and obese adults? A systematic review and meta- analyses. Disability and Rehabilitation. 2019. P. 1-13. DOI: https://doi.org/10.1080/09638288.2019.1688871

3. Bunaciu A. A., UdriŞTioiu E. G., AboulEnein H. Y. X-ray diffraction: instrumentation and applications. Critical reviews in analytical 
chemistry. 2015. Vol. 45, No. 4. P. 289-299. DOI: https://doi.org/10.1080/10408347.2014.949616

4. Clark S. M., Iball J. The X-ray crystal analysis of bone. Progress in Biophysics and Biophysical Chemistry: Progress Series. 2016. Vol. 7. P. 226. DOI: https://doi.org/10.1016/S0096-4174(18)30127-6

5. Clinical usefulness of bone turnover marker concentrations in osteoporosis / H. A. Morris et al. Clinica chimica acta. 2017. Vol.467. P. 34-41. DOI: https://doi.org/10.1016/j.cca.2016.06.036

6. Effect of the nano crystal size on the X-ray diffraction patterns of biogenic hydroxyapatite from human, bovine, and porcine bones / M. LondoñoRestrepo, et al. Scientific reports. 2019. Vol. 9, No. 1. P. 112. DOI: https://doi.org/10.1038/s41598-019-42269-9

7. Gritschmeier F., Lange K. W. Health effects of whole body vibration. Movement and Nutrition in Health and Disease. 2020. Vol. 4. P. 83-88.

8. Hlaing T. T. Compston JE. Biochemical markers of bone turnover-uses and limitations. Annals of clinical biochemistry. 2014. Vol. 51, No. 2. P. 189-202. DOI: https://doi.org/10.1177/0004563213515190

9. Minematsu A., Nishii Y., Imagita H., Sakata S. Whole body vibration at low-frequency can increase trabecular thickness and width in adult rats. Journal of musculoskeletal \& neuronal interactions. 2019. Vol. 19, No. 2. P. 169.

10. Pang M. Y., Lau R. W., Yip S. P. The effects of whole-body vibration therapy on bone turnover, muscle strength, motor function, and spasticity in chronic stroke: a randomized controlled trial. European journal of physical and rehabilitation medicine. 2013. Vol.49, No. 4. P. 439-450.

11. Savvidis C., Tournis S., Dede A. D. Obesity and bone metabolism. Hormones. 2018. Vol. 17, No. 2. P. 205217. DOI: https://doi.org/10.1007/s42000-018-0018-4

12. Shapses S. A., Pop L. C., Wang Y. Obesity is a concern for bone health with aging. Nutrition research. 2017. Vol. 39. P. 1-13.

DOI: https://doi.org/10.1016/j.nutres.2016.12.010

13. Smith K. B., Smith M. S. Obesity statistics. Primary care: clinics in office practice. 2016. Vol. 43, No. 1. P. 121135. DOI: https://doi.org/10.1016/j.pop.2015.10.001

14. The effects of fat-induced obesity on bone metabolism in rats / W. Li et al. Obesity Research \& Clinical Practice. 2017. Vol. 11, No. 4. P. 454-463. DOI: https://doi.org/10.1016/j.orcp.2016.12.001

15. Whole-body vibration mimics the metabolic effects of exercise in male leptin receptor-deficient mice / M. E. McGee-Lawrence et al. Endocrinology. 2017. Vol. 158, No. 5. P. 1160-1171.

DOI: https://doi.org/10.1210/en.2016-1250

16. Whole-body vibration training in obese subjects: A systematic review / M. Zago et al. PloS one. 2018. Vol. 13, No. 9. P. e0202866.

DOI: https://doi.org/10.1371/journal.pone.0202866

17. Whole body vibration training with repetitive interval musculoskeletal loading on bone in young women / J. Flores et al. Southern California Conferences for Undergraduate Research. 2017.

The article was received 2020.04.15 